\title{
RESPONSE
}

\section{I'm Not Your Carceral Other Vicki Chartrand}

aining insight into the prison is an important and challenging enterprise. In the prison, power operates through physical space, control of movement, and the regulations and rules that organize the daily activities and exchanges of those who live and work there. Systems of reward and punishment, codes of conduct both written and verbalized, and mechanisms of surveillance are just a few of the confining and forming activities found within. Common parlance today focuses on the prison's disciplinary and repressive character. As the authors in this issue show, however, disciplinary power is not only punitive and restrictive, but attempts to limit and habituate us to narrow understandings of incarcerated persons, ourselves, and our sense of justice. These forming activities and strategies become even craftier when the grand narrative is built on the idea of "reforming" people - as if this is somehow a laudable or achievable goal. One cannot help but think of modern colonialism's assimilation, segregation and elimination policies that continue to haunt our nations when "reform" is on the agenda - logics and techniques that are found throughout our social world and intensified in the punitive microsites of the prison. Insight into the prison can only be cultivated with those with a situated knowledge and who can therefore illuminate these carceral logics. Situated knowledge reveals more about ourselves and our social world as the logics found within the prison are also expressed throughout our everyday lives (Bandyopadhyay et al., 2013 , p. 29). Resisting both repressive and subtler regimes of power is not only important for those in prison, but for all of us as we struggle against systems of knowledge and technologies that attempt to shape our modes of thinking and ways of being, and that determine our "institutionally approved" behaviour. I'm not your carceral Other.

The carceral logics and techniques that proliferate our social world create and circulate so-called "criminal" populations through the segregation of lawbreakers, the deportation of immigrants, the containment of poverty, and the elimination of high-risk populations. As Craig Muhammed in this issue aptly points out, this framework in the management of populations is largely based on race, gender, class, sexuality, poverty and other intersections of oppression. Far from simply a disciplinary apparatus of control and repression, the prison is a mechanism to identify, differentiate, 
classify, filter, and govern bodies and our beliefs through the perpetual practice of defining, shaping, and dividing the carceral Other. The carceral Other signifies a body that can be segregated, assimilated, immobilized, modified, eliminated, or saved (Chartrand, forthcoming), all the while convincing us of this necessity. Whole populations are marginalized and then inscribed using "criminal" titles, along with other configurations such as "anti-social", "faulty thinkers" or "unadjusted". This largely depicts the interned as socially vulnerable, risky, burdensome, unstable or undeserving — in need of reform.

This knowing and shaping of the carceral Other is achieved through hierarchies, labels, testing, surveillance, classifications, policing, and confessions - practices found throughout our social world and intensified in the micro-sites of a prison system. Charles N. Diorio and Victor Becerra in this issue reveal these dividing practices in their articles that explore the day-to-day indignities experienced in the prison in terms of physical and mental health. The authors highlight some of the more subtler, hidden oppressions of carceral logics that result in medical neglect and delays, inappropriate or ineffective medical visits, and a general disregard for personal well-being. These practices of the prison are not always so visible or easy to identify, but nonetheless have destructive cumulative effects. Similarly in this volume, Tara Perry and Colleen Hackett reveal the subtly coercive nature of the "therapeutic community" that constructs prisoners with "cognitive distortions". As noted by Tara Perry while in prison, "I had the urge to offer my friend a hug, or at the very least, a hand on her shoulder. Doing so would have resulted in an automatic write up for a 'sexual misconduct'... The model prisoners internalize the belief, to varying extents, that expressing one's self through anger or engaging in a meaningful relationships while in prison is inappropriate, wrong, and shameful". This highlights the invasive character of carceral logics that seek to reform our very situated selves. As the authors further note, prisoner writing such as auto-ethnography provides us with these important understandings. This point is similar to Mary Bosworth's (1999, p. 155), who reveals how such subtle carceral logics are resisted by women in prison who find different ways to maintain their sense of identity "women manage their experiences of imprisonment by drawing on their sense of self which they ground in their (feminine) identities as mothers, girlfriends, and lovers". 
In the prison, officials often view acts of resistance as a failure to comply, manipulative, a form of cognitive dissonance, anti-social behaviour, and other fictions of a system designed to deny agency and self-expression. This very act of defining resistance is embedded in the strategic relations that privilege institutional knowledge in its attempt to control the circumstances and what is considered acceptable, reasonable, rational, or necessary. Melissa Munn and Chris Bruckert (2010) reject such institutional definitions in their work and make visible the objectives, purposes, strategies, tactics, and skills that characterize both the processes and practices of prisoner resistance. They further argue that it is exactly looking at these often obscured processes of resistance that allow us to appreciate its density, the multiple ways it operates, and the significance of individuals' social, personal or political capital. Resistance can therefore be understood in its diversity such as with prison riots (Carrabine, 2004), hunger strikes (Welch, 2009), prisoner committees (George, 2006), writing (Rymhs, 2008), jailhouse lawyers (Ben-Moshe, 2011), political theatre groups (Merrill and Frigon, 2015), court challenges (Jackson, 2002), or institutional complaints (Parkes and Pate, 2006). There are also the more subtle resistances such as feigning compliance, ignoring directives, developing personal codes of conduct and personal writing (Scott, 1990; McCulloch and Scraton, 2009). Carceral logics are not only resisted by rejecting or revolting against them, but also by making use of the institutional arrangements and discourses to recreate carceral space, experiences, and expressions of self.

In this issue, Gregory Webb points out the significance of self-awareness and expression in the prison and "[a]cknowledging the personal, social, legal and cultural topography of my situated-ness". The author further points out that, with little else, prison identity often turns into a commodity that is traded and invested in relations, serving as a mask to what is really being consumed - time. This example reminds us how resistance is never outside an expression of power, but rather how our situated-ness also shapes our expressions of resistance in attempts to transcend the "walls, wires, and bars". Where carceral logics endeavour to shape our understanding of self, the prison can also act as a mirror, not only for us to reflect upon ourselves, but the social world that stands behind us. Resistance emerges in the microsites of the prison where knowledge is in conflict with one another and within ourselves. 
As demonstrated in this issue, incarcerated persons continue to challenge, work through, break from and partition the lines of force found behind the prison walls. Deena Rhyms (2008) argues that prisoners provide a narrative that deflects and reshapes the vantage point from where resistances exist and can occur. These valuable accounts not only tell us about the prison, but of our own social makeup and the many ways we limit our own understandings and expressions of self when punishment and reform are on the agenda. Despite our "advances" and "best intentions" in what is referred to as penal reform, carceral power will continue to mask itself without the insights of those with situated knowledge. The accounts in this issue provide an entry into new understandings and approaches into a politics of autonomy and awareness that reframes a discussion for anti-prison politics, one that investigates both broad and subtle carceral logics, including those of our own - I'm not your carceral Other.

\section{REFERENCES}

Bandyopadhyay, Mahuya, Andrew M. Jefferson and Thomas Ugelvik (2013) "Prison Spaces and Beyond: The Potential of Ethnographic Zoom", Criminal Justice Matters, 91(1): 28-29.

Bosworth, Mary (1999) Engendering Resistance: Agency and Power in Women's Prisons, Aldershot: Dartmouth Publishing Company.

Carrabine, Eamonn (2004) Power, Discourse and Resistance: A Genealogy of the Strangeways Prison Riot, Aldershot: Ashgate.

Chartrand, Vicki (forthcoming) "Penal Tourism of the Carceral Other as Colonial Narrative", in Jacqueline Z. Wilson, Sarah Hodgkinson, Justin Piché and Kevin Walby (eds.), The Palgrave Handbook of Prison Tourism, London: Palgrave.

George, Amanda (2006) Prisoner Committees in Women's Prisons: A Report on Women's Prisoner Committees in California Canada and South Africa, Geelong: Deakin University.

Jackson, Michael (2002) Justice Behind the Walls: Human Rights in Canadian Prisons, Vancouver: Douglas and McIntyre.

McCulloch, Jude and Phild Scraton (eds.) (2009) The Violence of Incarceration, New York: Routledge.

Merrill, Elise and Sylvie Frigon (2015) "Performative Criminology and the "State of Play' for Theatre with Criminalized Women”, Societies, 5(2): 295-313.

Munn, Melissa and Chris Bruckert (2010) "Beyond Conceptual Ambiguity: Exemplifying the 'Resistance Pyramid' Through the Reflections of (Ex) Prisoners' Agency", Qualitative Sociology Review, 6(2): 137-149.

Parkes, Debra and Kim Pate (2006) "Time for Accountability: Effective Oversite of Women's Prisons", Canadian Journal of Criminology and Criminal Justice, 48(2): 251-285. 
Rymhs, Deena (2008) From the Iron House: Imprisonment in First Nations Writing, Waterloo: Wilfrid Laurier University Press.

Scott, J. C. (1990) Domination and the Arts of Resistance: Hidden Transcripts, New Haven: Yale University Press.

\section{ABOUT THE AUTHOR}

Vicki Chartrand, $P h D$ is an Associate Professor in the Department of Sociology at Bishop's University and is Prisoners' Struggles Editor for the Journal of Prisoners on Prisons. 